RACAR : Revue d'art canadienne

Canadian Art Review

\title{
Translating Music into Visual Form: The Influence of Music in the Work of Bertram Brooker
}

\section{Glenn Williams}

Volume 27, numéro 1-2, 2000

URI : https://id.erudit.org/iderudit/1069727ar

DOI : https://doi.org/10.7202/1069727ar

Aller au sommaire du numéro

\section{Éditeur(s)}

UAAC-AAUC (University Art Association of Canada | Association d'art des universités du Canada)

\section{ISSN}

0315-9906 (imprimé)

1918-4778 (numérique)

Découvrir la revue

Citer cet article

Williams, G. (2000). Translating Music into Visual Form: The Influence of Music in the Work of Bertram Brooker. RACAR : Revue d'art canadienne / Canadian Art Review, 27(1-2), 111-122. https://doi.org/10.7202/1069727ar
Résumé de l'article

Cet article se propose d'examiner l'influence de la musique sur la vie et l'oeuvre de Bertram Brooker. Dans ses expériences avec le son et la couleur, Brooker a été influencé par ses contemporains, Wassily Kandinsky, Georges Braque et Georgia O'Keeffe. La documentation suggère que Brooker était parmi les premiers artistes canadiens d'explorer la corrélation entre les arts et d'essayer des idées modernistes. Il a présenté ces idées à 250000 lecteurs dans sa rubrique "Seven Arts ", publiée dans les journaux Southam du 20 octobre 1928 au 15 novembre 1930. Ses écrits affirment que Brooker était un catalyseur pour des changements dans l'art canadien. Pour clarifier encore plus le rôle que la musique a joué dans l'oeuvre de Brooker, ses expériences musicales, sa poésie, et ses autres écrits sont discutés, en plus de sa connaissance de la littérature métaphysique et la théorie d'art contemporaine. Finalement, l'analyse est fait d'un certain nombre de ses peintures et dessins des années 1920 et 1930.
Tous droits réservés @ UAAC-AAUC (University Art Association of Canada | Association d'art des universités du Canada), 2003
Ce document est protégé par la loi sur le droit d'auteur. L'utilisation des services d'Érudit (y compris la reproduction) est assujettie à sa politique d'utilisation que vous pouvez consulter en ligne.

https://apropos.erudit.org/fr/usagers/politique-dutilisation/ 


\title{
Translating Music into Visual Form: The Influence of Music in the Work of Bertram Brooker
}

\author{
GI.ENN WiLLIAMS, YORK UNIVLRSITY
}

\begin{abstract}
Résumé
Cet article se propose d'examiner l'influence de la musique sur la vie et l'œuvre de Bertram Brooker. Dans ses expériences avec le son et la couleur, Brooker a été influencé par ses contemporains, Wassily Kandinsky, Georges Braque et Georgia O'Keeffe. La documentation suggère que Brooker était parmi les premiers artistes canadiens d'explorer la corrélation entre les arts et d'essayer des idées modernistes. II a presenté ces idées à 250000 lecteurs dans sa rubrique «Seven Arts», publiée dans les journaux Southam du 20 octobre
\end{abstract}

1928 au 15 novembre 1930. Ses écrits affirment que Brooker était un catalyseur pour des changements dans l'art canadien. Pour clarifier encore plus le rôle que la musique a joué dans l'œure de Brooker, ses expériences musicales, sa poésie, et ses autres écrits sont discutés, en plus de sa connaissance de la littérature métaphysique et la théorie d'art contemporaine. Finalement, l'analyse est fait d'un certain nombre de ses peintures et dessins des années 1920 et 1930.
$\mathrm{I}$ n the early part of the twentieth century, artists like Bertram Brooker who chose to move beyond representation, discover the "higher self", and investigate other dimensions of thought and existence often turned to music for inspiration. The relationship of music and art is to a certain extent both interpretive and imprecise, the subject of an ongoing study. A myriad of parallels and insights have been proposed by musicians, artists and scholars alike. The majority of these studies share the common assertion that music and art originate at the same source though they diverge afterwards.

For Bertram Brooker, music was an ideal and natural source of inspiration. Brooker expressed this affinity for music in an essay encitled "The New Game of Music-Colour" written in 1930. In the article, Brooker described himself as a "highbrow from Canada ... [who] painted musical interpretations in vast numbers ... [and] calls it 'giving plastic expression to [his] responses to music'." In Brooker's first series of non-objective works, Noise of a fish and Oozles of the early 1920s, musical themes were also mentioned. ${ }^{2}$ The influence of music asserted itself well into the 1940s as evidenced by such paintings as Symphonic Forms of 1947 and Leaf Sonata (fig. 1) of 1948. Victor Brooker believed that his father began exploring the nexus between music and art from childhood: "He [Bertram Brooker] had been doing things ever since he was a child, one watercolour painting my sister still has was the result of an cmorional feeling, he had about a hymn ... Abide with me."

Brooker, who was also active as a dramatist, novelist, amateur musician, poet, free-lance journalist and in advertising, investigated modernist ideas in a syndicated weekly column "The Seven Arts". This was published by the Southam newspaper chain from 20 October 1928 to 15 November 1930. In his column, Brooker discussed architecture, sculpture, philosophy, technology, modern music, drama, dance, poetry and painting.

Brooker's writings were, on occasion, polemical. In the 9 March 1929 column, he discussed a debate between himself and Fritz Reiner, a well-known musician who had recently conducted three programmes at Massey Hall. Brooker indicated that "Reiner took the view that there is no relationship between musical composition and plastic composition. Consequently he heartily disliked the musical titles that I have given a number of my abstract drawings." ${ }^{4}$ In his rebuttal, Brooker suggested that the superior musician detested "program" music and "wants music to be 'pure' and 'abstract'. Yet when painters or sculptors attempt to go in the same direction the musicians seem to be ... almost the last persons to understand or appreciate what is being attempted." 5 When Brooker first exhibited his abstract paintings at the Arts and Letters Club in Toronto in January 1927, he described them as "expressions of musical feeling; one a direct interpretation of a mood suggested by the Largo of Dvořák's New World Symphony." A colleague of Brooker's, the director of the Mendelssohn choir, G. D. Atkinson, who also attended the show, is said to have remarked "My God, they're all about music ... must be Bert Brooker."7 Though no definitive list of the works exhibited in January 1927 still exists, Abstraction - Music (fig. 2) and Toccata (1927), which derive from tempera paintings begun several years earlier, were included. ${ }^{8}$

These works appear to be highly personal responses to musical expression and suggest that "Brooker appears to have drawn images from within himself rather than from the world of art." Later paintings such as Ascending Forms (fig. 3) or Evolution (fig. 4), on the other hand, illustrate how current trends in the visual arts helped Brooker forge his distinctive amalgam of music and art. These pieces suggest that Brooker was well aware of "similar experiments that [had] been carried on by Braque, Kandinsky, and other famous European painters." 10 In the 19 October 1929 edition of "The Seven Arts" column, Brooker said that "some painters are concerned simply to compose as a musician does - using rhythms and colours to achieve a harmonious whole or unity." 11 Other artists who had explored the possibilities of musical expression in paintings and drawings included Paul Klee. Klee, an accomplished violinist, "applied fugal reversal and reflection to hues as well as to tones in his 'magic-square' compositions." 12 One of his colleagues at the Bauhaus, Lyonel Feininger, composed fugues for the harmo- 
Figure 1. Bertram Brooker, Leaf Sonata, 1948. Watercolour, $37 \times 27 \mathrm{~cm}$. Toronto, Hart House permanent collection (Photo: Partners Integrated, 236 Lesmill Road, Toronto, Ontario).

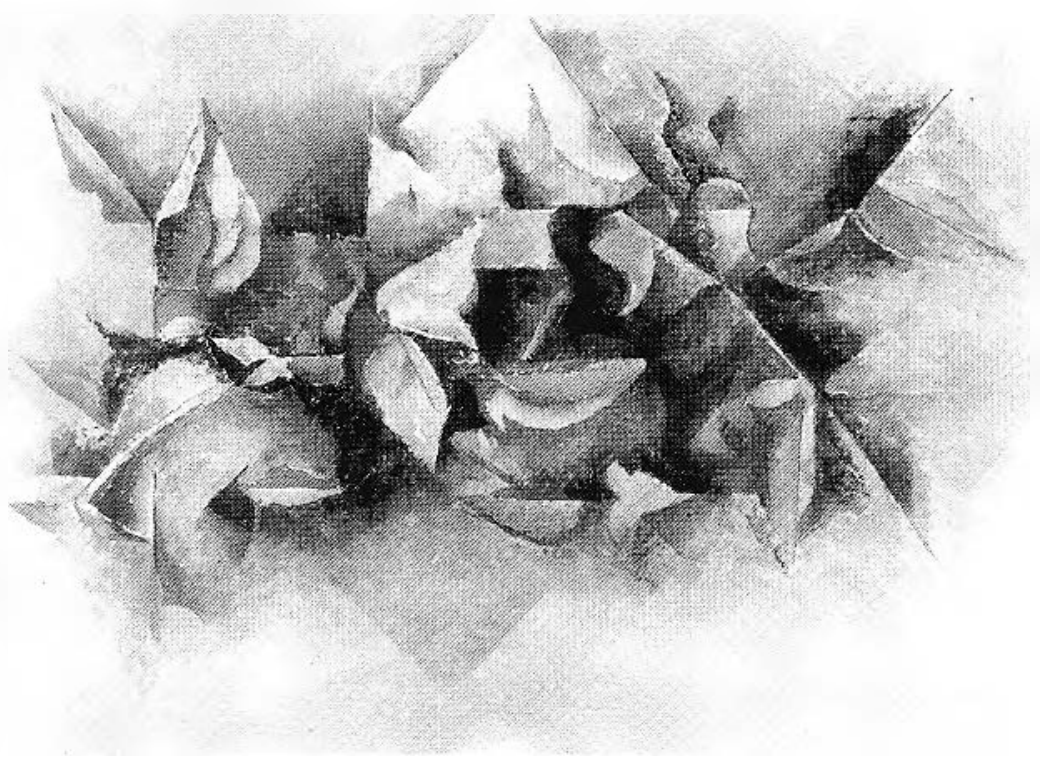

Figure 2. Bertram Brooker, Abstraction - Music, ca. 1927. Oil on card, $43.2 \times 61.0 \mathrm{~cm}$. London Regional Art and Historical Museums, F.B. Housser Memorial Collection (Photo: Ian MacEachern).

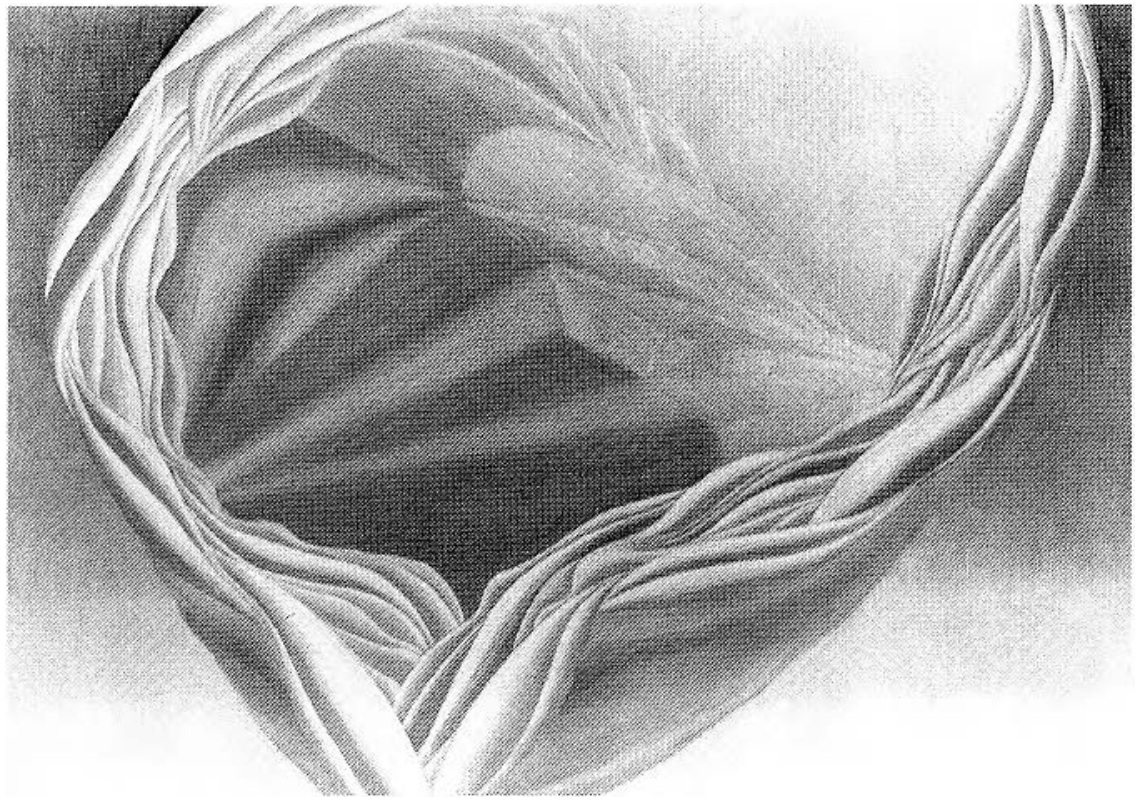

their ideals and objectives. "Music was 'abstract', yet at the same time expressive of profound spiritual truths." ${ }^{14}$ As artists such as Wassily Kandinsky, Luigi Russolo and Morgan Russell abandoned conventional representation, they encountered problems with organizational criteria and maintaining cohesion within their work. Music, which was based on well-established theoretical principles such as scales, key signatures and harmony, provided them with a relatively stable model to emulate.

\begin{abstract}
Not until the twentieth century do we encounter such determined efforts to apply musical principles to painting not simply to find pictorial cquivalents for musical elements such as rhythm or syncopation, but actually to translate musical structures - fugue, canon and so on - into paint. ${ }^{15}$
\end{abstract}

For Bertram Brooker, music as the least material of the arts was considered a superior instrument through which to express the inner forces. In this respect, Brooker's ideas were in accord with those of Schopenhauer. He had designated music as the highest form of artistic expression, surpassing all others in its ability to convey "the Platonic Idea, unfettered by any 'material' whatever."16 In an article entitled "The Woes of Music Criticism with a Few Odd Examples", Brooker quoted a passage from Plays, Acting and Music which reinforced his own point of view: "The reason why music is so much more difficult to write about than any other art, is because music is the one absolutely disembodied art, when it is heard, and no more than a proposition in Euclid, when it is written ..."17

A resident of Toronto from 1921 until his death in 1955, Brooker developed close ties with many notable personalities, many

nium and piano and maintained that Bach "finds expression also in my paintings." 13

Artists' concern for problems of composition further prompted them to look to other art forms for inspiration and direction. Music was the medium to which many of them turned as it embodied and was, to some extent, compatible with of them involved in music in the Toronto area. According to Victor Brooker, his father's inner circle of friends included Vincent Massey, Ned Pratt, Fred Housser and the Adaskins. "Other lasting friends ... [were] Herman Voaden, Healey Willan, Fred Banting, Ernest MacMillan ... [LeMoine] Fitzgerald and [Arthur] Lismer - Charles Comfort ..."18 Toronto was a key 
Figure 3. Bertram Brooker, Ascending Forms, ca. 1929. Oil on canvas, $76.2 \times 61.6 \mathrm{~cm}$. Ottawa, National Gallery of Canada (Photo: National Gallery of Canada).

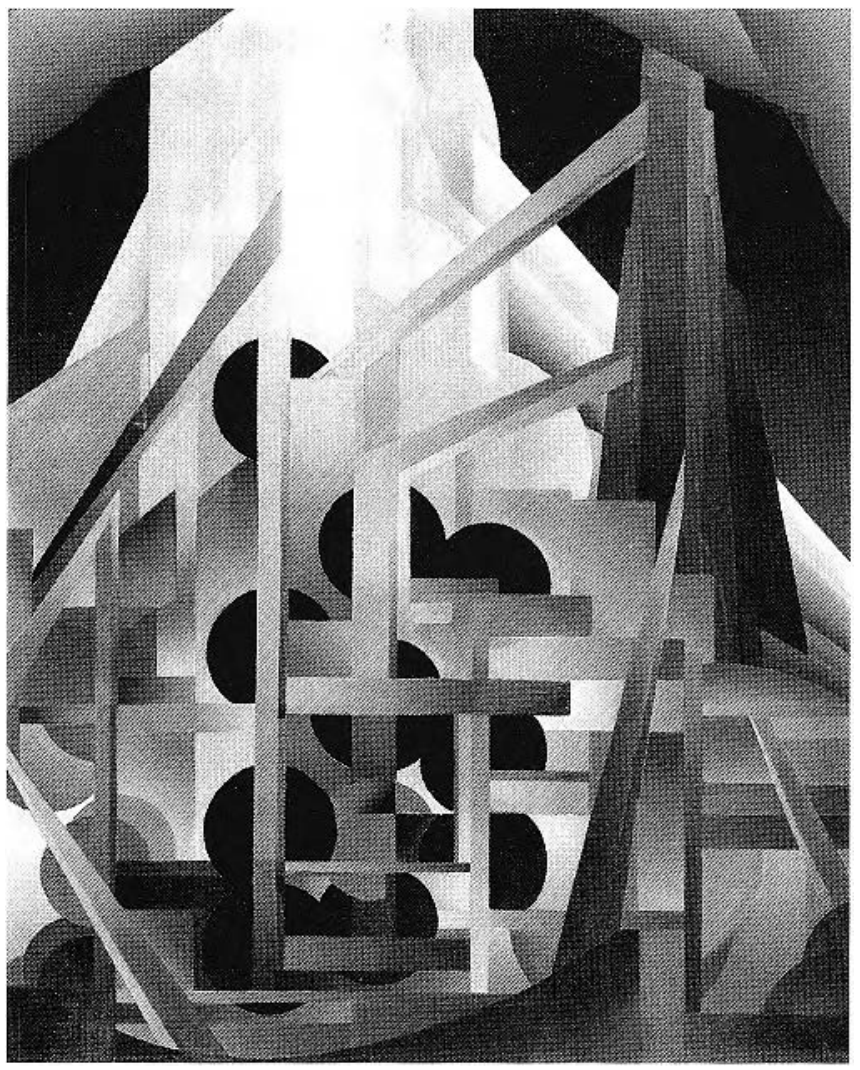

stop for international touring artists in the 1920s. It attracted many creative individuals from the USA and Europe. One of these, Thomas Wilfred, was an acquaintance of Brooker. In the 23 February 1929 edition of "The Seven Arts" column, Brooker rclates: "We had dinner [in New York] with Thomas Wilfred, inventor of the Clavilux known as the 'colour organ' which projects moving forms and colours on a lighted screen." 19 Brooker later recounted how he had attended several clavilux recitals given by Wilfred in Toronto (at the Georgian room in Eaton's and at Hart House).

In "The Seven Arts" columns, Brooker frequently used musical references in conjunction with dance, drama and literature. In his 12 October 1929 column, Brooker described current trends in dance as forms of "musical visualization". ${ }^{20}$ The following week, he wrote that the link between drama and music had been reestablished vis-à-vis "incidental music, musical comedies, opera and talking movies." 21 Bertram Brooker also discussed the rhythmic prose of Gertrude Stein and the later work of James Joyce, authors who experimented with words in much the same manner as abstract artists used forms and colours to construct a pattern. In this regard, Brooker was amongst the first group of Canadian artists who understood and actively promoted the interrelationship of the arts.
Figure 4. Bertram Brooker, Evolution, ca. 1929. Oil on canvas, $76.4 \times 61.5 \mathrm{~cm}$. Ottawa, National Gallery of Canada (Photo: National Gallery of Canada).

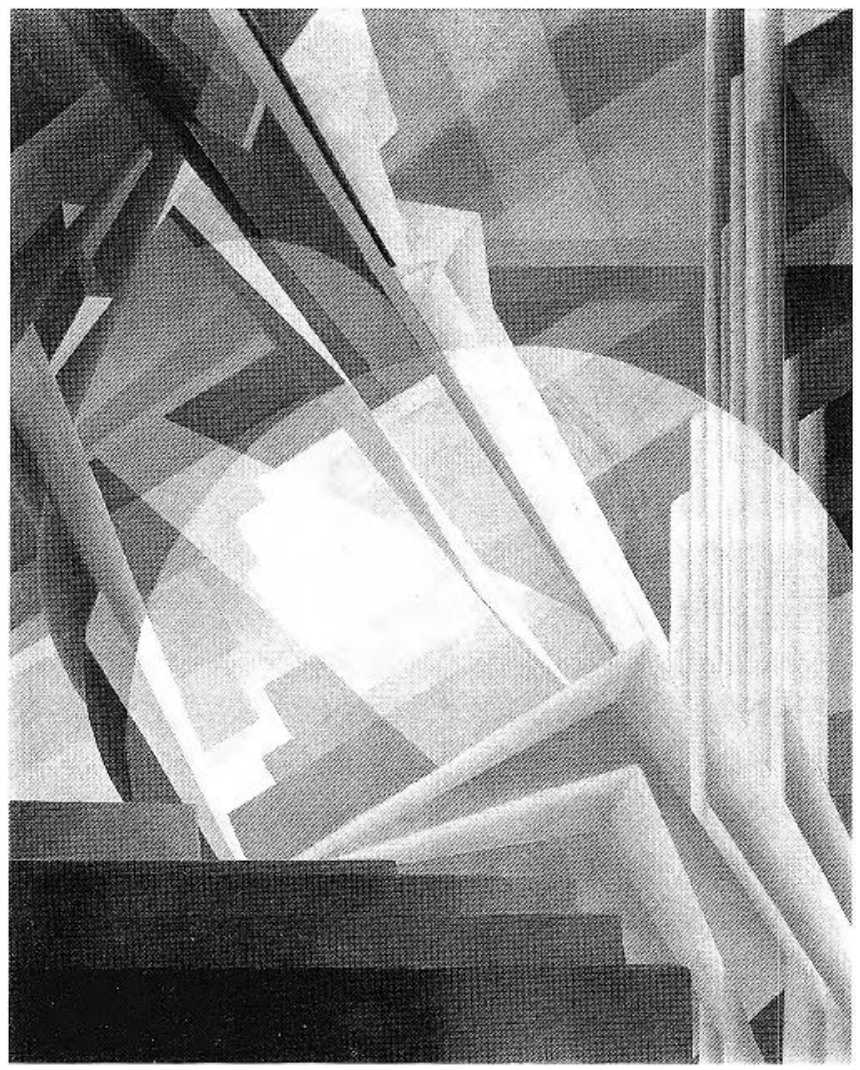

European and American artists had also investigated other mediums and the parallels between the art forms. In Germany, Kandinsky had written plays and poems; while in Italy Luigi Russolo experimented with sound through the development of his Noise Intoners; and composers like Schoenberg produced paintings. ${ }^{22}$ Americans like Morgan Russell and Stanton Macdonald-Wright (members of the Synchromist group) worked on plans for a Kinetic Light Machine which would coordinate sound and moving images. ${ }^{23}$ Morgan Russell was, in turn, influenced by the systematic colour theory developed by Percyval Tudor-Hart who proposed that "the twelve chromatic intervals of the musical octave ... have corresponding sensational and emotional qualities to those of the twelve chromatic colours." 24

Although Bertram Brooker's position as an innovator can be debated, his emphasis on the modernist concepts of interpretation, intuition and experimentation explain why he is widely regarded as a pioneer and a catalyst for change in Canadian art. Brooker's exploration of these concepts led him to the conclusion that a truly modernist work, whatever its discipline, was the sum or interrelationship of its parts.

In other words even the selected material "left in" seems to possess little significance when taken apart and analyzed 
separacely. A bar of "Rugby" or of "Pacific 231" yields no hint of the total impression created by Honegger's music when experienced as a whole. ${ }^{25}$

It is particularly interesting to look at Brooker's attempts to visualize and interpret musical form and structure in his art; they raise a number of problematic issues:

- As there is no pictorial equivalent for harmony, how do artists attempt to emulate or capture its transparent nature in their work?

- In the process of interpreting rhythm, be it fast, slow or syncopated, how does one suggest motion?

- Is it possible to suggest the continuity and duration of a melodic phrase through line and form?

- How can the artist utilize music as a vehicle to travel beyond the world of natural appearances and into the realm of the immaterial (the fourth dimension)?

- What role does colour play in the development of the synaesthetic process?

In order to better appreciate the circumstances that may have inspired Brooker to visualize musical form in pictorial language, we have to examine his musical experiences as well as his interest in art history and metaphysical literature. There are further clues in Brooker's poetry and other writings that illuminate and elucidate the artwork. By investigating Brooker's musical influences, we can determine the depth of his knowledge and how music was an enduring force throughout his life. Documentation suggests that Brooker was an enthusiastic amateur with limited musical skills; singing was his primary outlet for musical expression as he did not play an instrument or compose music. He once asked Healey Willan to write the musical accompaniment to a Brooker libretto, but the composer declined. ${ }^{26}$ According to Brooker's wife, Mary Aurilla, music remained a lasting influence in his work: "Music inspired more than three-quarters of his work," agreed Mrs. Brooker. "I called him the frustrated musician ... Much of his work came fresh and quick from the inspiration of a concert heard perhaps only that evening." 27

Though Brooker's musicianship skills were limited, he was certainly able to read music. He had sung in several choirs, including the St Mary's Anglican choir in Portage la Prairie and the prestigious Mendelssohn choir which he joined in $1921 .{ }^{28}$ Previously, Brooker's responsibilities at the Manitoba Free Press (now the Winnipeg Free Press) included that of drama editor, automobile editor, promotion manager and music critic for two and a half years. ${ }^{29}$ In an article entitled, "The Woes of Music Criticism with a Few Odd Examples", Brooker revealed his knowledge of basic music theory: "As I have said the poor music critic has to deal chiefly with symbols, and one cannot talk poetically about dominant sevenths and minor ninths [intervals]." 30 His review of Healey Willan's A Song of Canada in "The Seven Arts" column of 27 September 1930 also indicates that Brooker was conversant with musical form and structure:

It is a fine, broad, dignified composition, the first verse sung in unison, the second in harmony, and the third in unison again until the coda is reached when the voices break into harmony again and the anthem lifts to a big climax. ${ }^{31}$

Brooker's review of the aforementioned composition, performed by the Canadian National Exhibition Chorus, suggests that over the years he had developed critical listening skills. A frequent and enthusiastic concert-goer, Brooker found it difficult to resist the urge to compare one musical performance against another. However, he believed this was a mistake as "it puts one in an intellectual frame of mind, and the emotional impact of the music is blunted by the constant comparisons one makes between the performance in progress and the memories of past performances." 32 Although Brooker's concert reviews expressed some interest in matters of technique and tone, his comments in the 15 February 1930 "Seven Arts" column implied that his feeling for music transcended intellectual and analytical concerns: "Perhaps it is because for me music is the supreme experience in life. Nothing else - not even Nature affects me so deeply." 33

Brooker's affinity for music was further strengthened by his contact with Canadian musicians, Harry Adaskin and Sir Ernest MacMillan, who shared his passion for the music of Bach. In the 4 May 1929 "Seven Arts" column, Brooker enlarged upon his feelings for Bach: "Harry Adaskin, one of the Hart House String Quartet, was at our house the other night, and ... we talked of Bach. We were agreed that Bach's effects are much less obvious than those of almost any other composer, and the conversation was really an attempt to analyse the secret of his magic." 34

Brooker greatly admired Ernest MacMillan's skills as a conductor, composer and pianist and made a point of following his activities, referring to him frequently in his weekly columns. In the 21 December 1929 column, Brooker mentioned a recent performance of Bach's St Matthew Passion in which he attributed the fine quality of the rendition to MacMillan's conducting and leadership skills. It is probable that Brooker attended MacMillan's annual presentation of Bach's St Matthew Passion on a regular basis, as this was one of his favourite choral works. ${ }^{35}$ According to Robert Fulford, MacMillan and Adaskin were frequent guests at Brooker's home: "The Hart House String Quartet sometimes played there and the guests at a party might include Frederick Banting, Lawren Harris and Sir Ernest MacMillan."36 
Bertram Brooker often recounted his early musical experiences and the way they heightened and shaped his perceptual abilities in "The Seven Arts" columns. Criticizing a Purcell opera, he wrote: "It did not appeal to me as anything like so fine as the Purcell chants and hymn tuncs that I grew up with as a choirboy in the south of London." ${ }^{37}$ There were other significant musical events which took place in Portage la Prairie, Manitoba, where Brooker moved with his family at the age of seventeen.

In the 20 April 1929 column, Brooker recalled his reaction upon hearing Beethoven's Appassionata sonata performed by Mark Hambourg at the opera house in Portage la Prairie. Brooker's comments suggest that the experience was tantamount to a spiritual reawakening: "I became conscious, for the first time of the world of tone." 38 Later that year (14 September 1929), Brooker reminisced about his reunion with James McRae, the organist of Knox United Church in Portage la Prairie. Naturally, music formed a large part of the discussion "and then he played me Bach's D minor Toccata and Fugue, sitting there alone together in the reverberating church." ${ }^{39}$

While Bertram Brooker was clearly moved by religious music as well as Beethoven's music, he also appreciated the work of such twentieth-century masters as Debussy, Prokofiev and Honegger. Brooker referred to Debussy in the 15 December 1928 column: "Mme. Carry Ysaye Haris ... sang a group of songs by Debussy at the evening of French music given lately at Toronto Art Gallery." ${ }^{40}$ In a subsequent column, Brooker said that he had arranged for a group of friends to listen to the following programmc:

$$
\begin{gathered}
\text { Pacific } 231 \text { - Honegger - orchestra } \\
\text { Love of the Three Oranges - Prokofiev - orchestra } \\
\text { St Matthew's Passion - Bach - orchestra and chorus (German) } \\
\text { St John's Passion - Bach - orchestra and chorus (Belgian) } \\
\text { Prelude in E flat - Bach - orchestra } \\
\text { Variations Symphoniques - Franck - piano and orchestra (Cortot) }
\end{gathered}
$$

This admiration extended to twentieth-century Canadian composers such as Healey Willan and Claude Champagne, who had incorporated folk melodies into some of their symphonic pieces. In the 15 December 1928 column, Bertram Brooker described Claude Champagne's Suite Canadienne which had just been performed in Paris: "The work, although based on four old chansons, is not merely a choral work with orchestral accompaniment, but is built into symphonic unity ..."42 Brooker's observations disclose that he understood how composers draw their inspiration from the former (folk music) and translate it into the latter (classical).

In fact, Bertram Brooker could be considered an amateur ethnomusicologist. He listened to and absorbed other folk mu- sic traditions, including Icelandic and Indian. ${ }^{43}$ Brooker's account of Indian music in the 9 March 1929 column indicates that he was moved by the evocative, mysterious quality of these ancient melodies. Their latent primeval power had the potential for provoking visual impressions: "Most of the ancient melodies have become definitely associated with certain ideas - such as Sunrise, Loneliness, Mountains and so on." ${ }^{44}$ In "The Seven Arrs" column, Brooker discussed the potential of music for stimulating the senses and transporting one beyond the confines of the external world: "It seems to me that the intensest enjoyment of music is in direct proportion to the ability of the hearer to divorce himself from the physical world and from associations with natural scenes and human passions." ${ }^{25}$

Brooker referred to the musical experience as contemplative and meditativc; a state of mind which seemed to embrace detachment, disinterestedness, aesthetic distance; qualities that suggested the influence of eastern philosophies of art and poetics. In his 1 November 1927 Hart House address, Brooker alluded to another state of mind: "cosmic consciousness" as recorded by R. M. Bucke. "It is more than 20 years since Dr. Bucke, the friend of Whitman, wrote his book Cosmic Consciousness, in which he records numerous cases that had come to his attention." 46

As Brooker saw it, the moment of "cosmic consciousness" occurs when the self rises above the body to become one with the universal forces to achieve a state of ecstasy and the sensation of infinity. ${ }^{47}$ For Brooker, this limitless universe or fourth dimension which exists beyond our narrow conception of time and space was most easily accessible through music: "Brooker's urge to paint verb-'movement' (capable of propelling him toward heaven) rather than noun-'objects' (that can only ground him in the nominative context of the earth) was rooted in a determination to bridge the gap between the real and the ideal by means of this upward/ascending passage." 48

Brooker's conception of this higher plane of existence alludes to the ideas of P. D. Ouspensky. Ouspensky's view of "cosmic consciousness" was, in turn, influenced by Hindu philosophy and the writings of Kant, C. H. Hinton, H. P. Blavatsky, R. M. Bucke and many others. The Russian philosopher believed that "cosmic consciousness is also possible of attainment through the emotion attendant upon creation - in painters, musicians and poets." ${ }^{49}$ Ouspensky's Tertium Organum was cited in a supplement to Brooker's itinerary of "Books that have influenced me". 50 Furthermore, a letter from August Belden indicated that Brooker had recommended Tertium Organum to his friend, who agreed with him that it was a work of some significance. ${ }^{51}$

In Tertium Organum, Ouspensky suggested that "The sensation of the unity of all ... [as well as] a new sensation of time, the sense of infinity; joy or horror; knowledge of the whole in 
Figure 5. Bertram Brooker, The Finite Wrestling with the Infinite, ca. 1927. Oil on canvas, $112.4 \times 81.3 \mathrm{~cm}$. Mendel Art Gallery and Civic Conservatory (Photo: Grant Kernan, A.K. Photos, Saskatoon, SK)

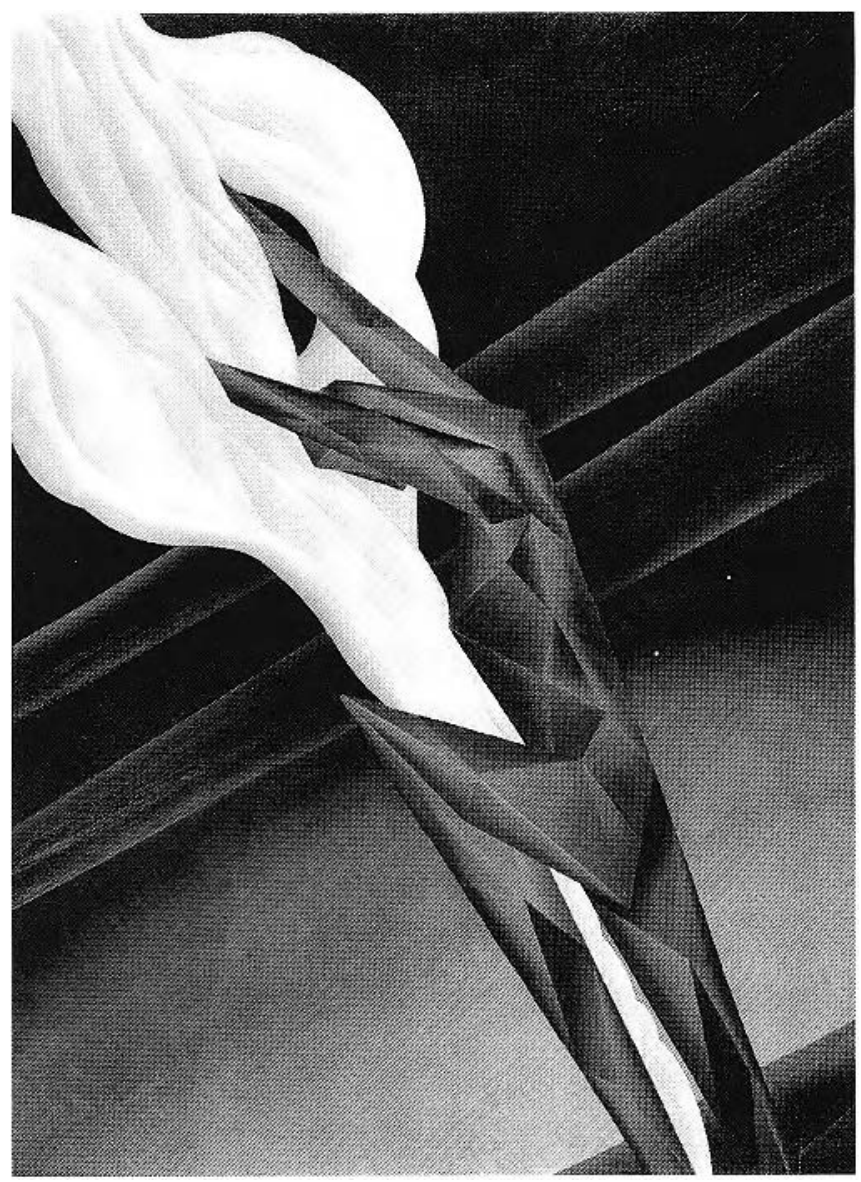

the part; infinite life and infinite consciousness" $\$ 2$ were germane to the mystical experience. Brooker found support for his ideas in Ouspensky's assertion that all artistic endeavour seeks to clarify and illustrate the differences between things by revealing the mysterious forces at work beneath the surface: "The phenomenal world is merely a means for the artist - just as colours are for the painter, and sounds for the musician - a means for the understanding of the noumenal world ..."5.3

Ouspensky's emphasis on the inner life or noumenal world, his reevaluation of three-dimensional time, space and matter as well as his scepticism of positivist science encouraged artists like Bertram Brooker to look beyond the material world for inspiration. In Abstraction - Music and The Finite Wrestling with the Infinite of 1927 (fig. 5), "he is dealing ... with forms that are not solid or real, with a universe that is in an infinite flux of being, of thought." 54 Brooker created the sensation of ever-becoming, ever-evolving by setting these interwoven, fluid forms against an indeterminate background. In Abstraction - Music (fig. 2), he communicated the feeling and vigour of musical expression in a series of lightly coloured, rising, twisting shapes.
The same interest in the interrelationship of the arts and the references to music that informed Brooker's artwork also shaped his voice as a poet. In his poetry, Brooker used musical rhythms and sounds as well as combinations and/or patterns of words to express his inner life and address the metaphysical issues that absorbed him. Bertram Brooker referred to Canadian poets Wilson Macdonald, E. J. Pratt, John Linnell and Fred Housser (who were all exploring similar ideas in their work) in "The Seven Arts" columns. For example in the 22 June 1929 column, he indicated that Housser was investigating the possibilities of metaphysical poetry, as was Brooker himself who delved into literary experiments with blank verse and drama at this time. One of these experiments may have been his The Death of a Peacock, a poetic work with a theatrical setting:

\section{The Death of a Peacock}

The stage is a great yawning cavern curtains ascend and descend vaguely in the inky gloom oboes and horns give out a stately air

a faint glow illumines the stage faint growing lighter lighter a background is dimly discerned tall poplars rising from behind a balustrade

the marble of the balustrade gleams the light increases programmes rustle everywhere

rustle ... rustle ... rustle everywhere in the crowded, silent theatre

whispers are heard Kalinova ... Kalinova

... presently the première danseuse appears

a gorgeous headdress of osprey feathers encircles her

brow which is like ivory 55

In The Death of a Peacock, Brooker enhanced the drama through the use of musical sounds and phrasing. Sights, sounds, movement and textures merge to evoke the sensation of synaesthesia. The image of the protagonist/dancer Kalinova, who is introduced by "oboes and horns [which] give out a stately air" works in concert with the theatrical lighting and the "programmes [that] rustle everywhere." Birk Sproxton suggests that this interplay of musical phrasing, words and images is analogous to the "stream of consciousness" where the "narrative aim is to suggest the full range of contents of an individual character's inner life. This suppression of sentence divisions tends to foreground the sound dimensions of the writing." 56

In his critique of e.e. cummings' poetry in the Canadian Forum, "he [Brooker] analysed this metaphysical verse as tending 'towards the mathematical and the musical.' It was mathematical in being both precise and measured; it was musical because of both the abstract arrangements and the patterns of sounds." 57 While describing cummings' obsession with death, 
Figure 6. Bertram Brooker, Fugue, 1930. Pen and ink on wove paper, $28.8 \times 33.1 \mathrm{~cm}$. Toronto, Art Gallery of Ontario (Photo: Art Gallery of Ontario).

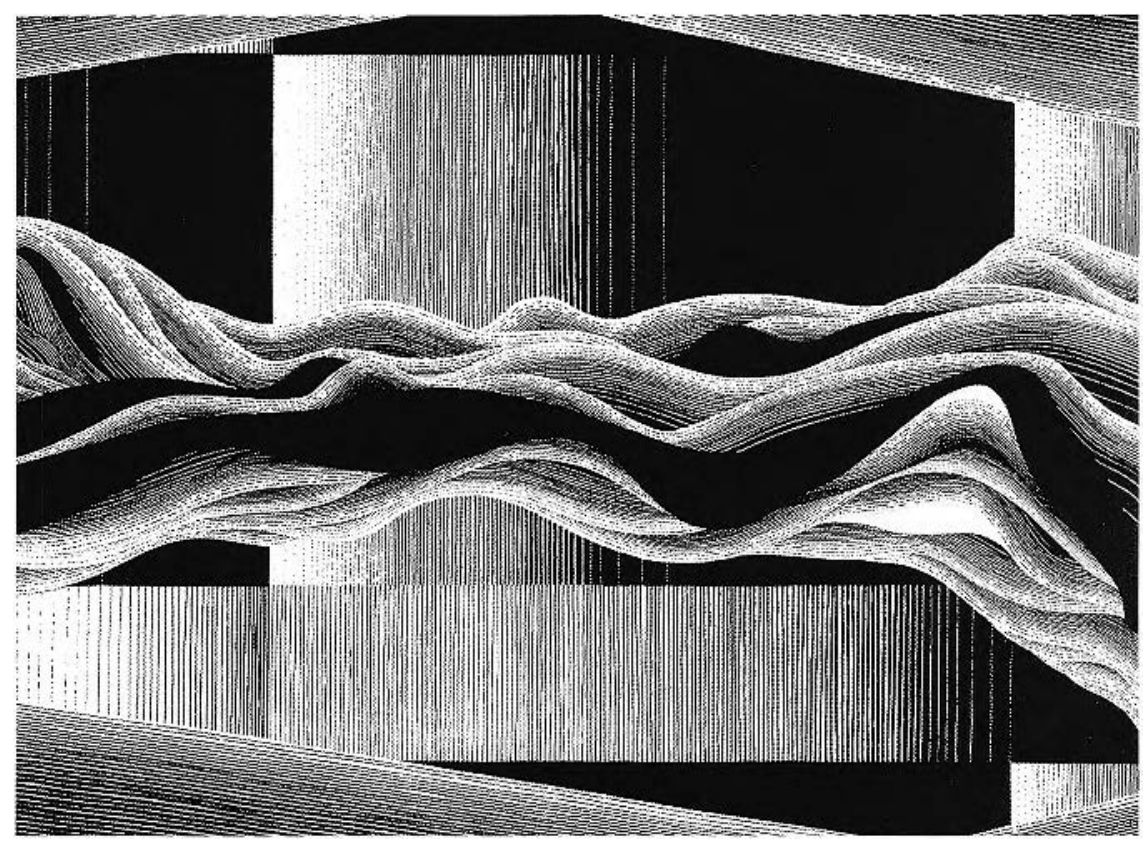

music: "One accepts a composition in mobile colour as freely as music, with the mind quiescent, the emotions responsive, the world well forgotten." 63 Cheney extolled the virtues of mobile colour: "I found in it, too, something of that quality which is so hard to describe, which metaphysicians call the fourth dimension." 64

In the late 1920s and the early 1930s, Brooker endeavoured to recreate the sensation of movement and sound in such paintings as Fugue, Duet 1.17, Chorale (Bach), Sounds Assembling, Allelujah, Ascending Forms and Resolution. The dramatic and musical quality of these pieces is characterized by Brooker's colour schemes as well as a variety of curvilinear and geometric forms which appear to expand beyond the confines of the picture frame. In Chorale (Bach), Sounds Assembling, Allelujah and Ascending Forms, the dynamic and encrgetic interaction of colour and form generates a myriad of spatial dis-

Brooker once again alluded to musical terminology: "Over and over again he resolves the chaotic development of his poems by swinging suddenly into a major chord in which the deep reverberations of death are dominant." 58 Perhaps the major chord or triad was a musical metaphor for the fusion of thought and experience, manifest in the fourth-dimensional realm.

Brooker's attitudes towards the arts were further shaped and informed by theoretical art historical writings. In "The Seven Arts" column, Brooker cited authors "whose books I have been studying for several years past", 59 including R. H. Wilenski's The Modern Movement in Art, Clive Bell's Art, Vernon Blake's Relation and Art, Frank Rutter's Evolution in Modern Art and Sheldon Cheney's A Primer of Modern Art.

With respect to the relationship of colour and sound, as well as colour manipulation via electronic means, Brooker was most likely influenced by the writings of Sheldon Cheney. In his A Primer of Modern Art, Cheney discussed "The Art of Mobile Colour" in which he examined the expressive capabilities of electronic mobile colour lighting (the Clavilux) as conceived by Thomas Wilfred. ${ }^{60}$ Cheney suggested that when artists abandoned "the materials for structure and organization in [their] canvasses, there was need for some other element beyond colour harmonies and structureless colour form."61 This other element was, according to Cheney, "movement in time [and] when [artists have] gained that [their] art has ceased to be painting, has become mobile colour." 62

Cheney described a Clavilux recital at Wilfred's "trial theater" in Long Island as an art form with the expressive power of tortions and directional thrusts which in some cases suggests the illusion of movement. Brooker revealed his penchant for energy in painting in "The Seven Arts" column: "Yet art, if it is art at all, is always living. It transcends classification and bursts open the enclosing walls of galleries." 65

Though a number of musical forms were explored by Brooker as a premise for visual connections, the fugue with its taut yet adaptable structure was one of the more interesting and challenging models to follow. The qualities manifest in the fugue such as repetition, inversion, diminution, augmentation, contrary motion and modulation offered opportunities for creative expression and interpretation on the two-dimensional surface. Artists, seeking to re-create the elements of fugal structure, "investigated the possibilities of inversion, of mirror effects, of overlapping, and of the interpenetration and synchronization of events ... principles of fugal construction [which are] all used in music to build a temporal order." 66 Brooker tried to capture some of these qualities in an ink drawing entitled Fugue (fig. 6). Here, the artist constructed an acoustical environment where the fluid "ribbon-like bands" 67 of the foreground evoke the rapid pace and melodic passages of Bach's Toccata and Fugue in $F$ major, BWV 540 for organ.

In Fugue, the fluid interwoven strands of various widths express the rise and fall and the rhythmic curve of the subject. The subject is a distinctive melody, consisting of no less than four measures, that is repeated in a cyclical fashion at different pitch levels (soprano, alto, tenor and bass). Brooker uses these elongated spiraling coils to recreate the layering that occurs in 
Figure 7. Bertram Brooker, Duet 1.17, 1931. Ink on paper, $28.6 \times 36.8 \mathrm{~cm}$. Toronto, Ant Gallery of Ontario (Photo: Ron Vickers).

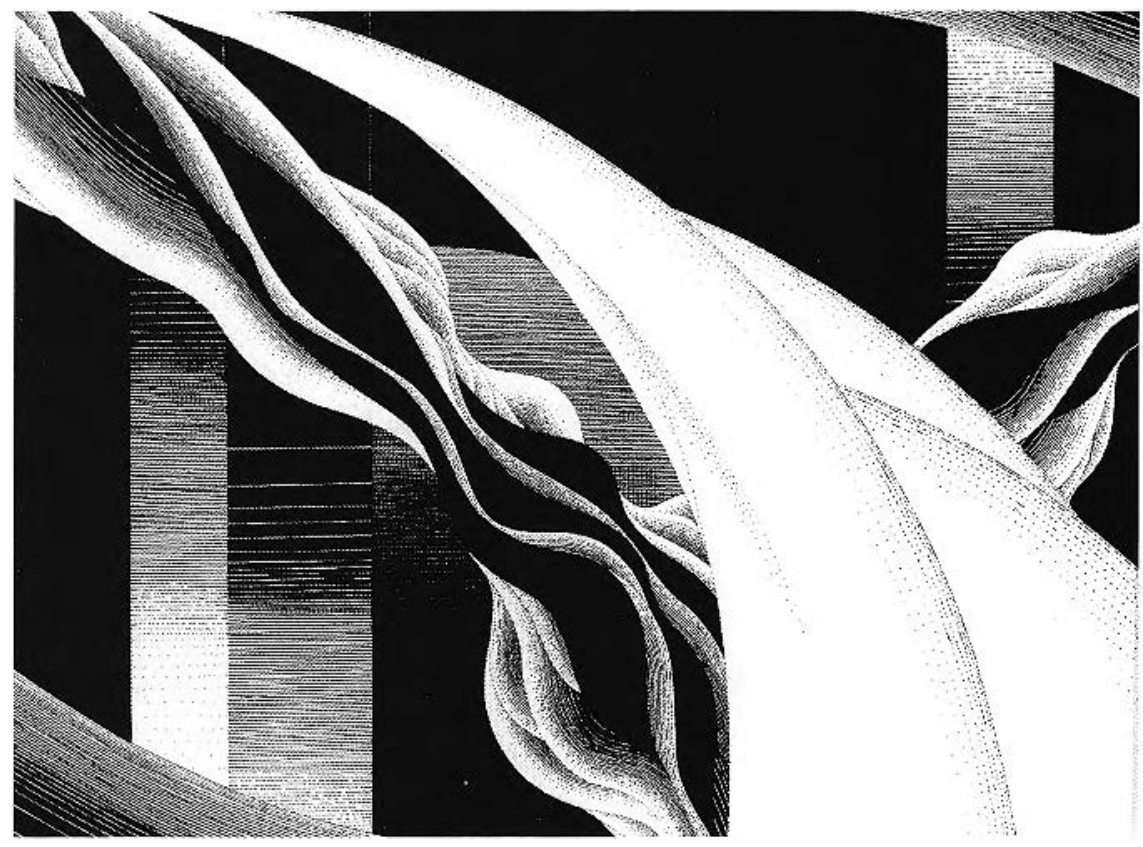

Figure 8. Bertram Brooker, Chorale (Bach), ca. 1927. Oil on canvas, $61.0 \times 43.7 \mathrm{~cm}$. Toronto, Art Gallery of Ontario (Photo: Carlo Catenazii).

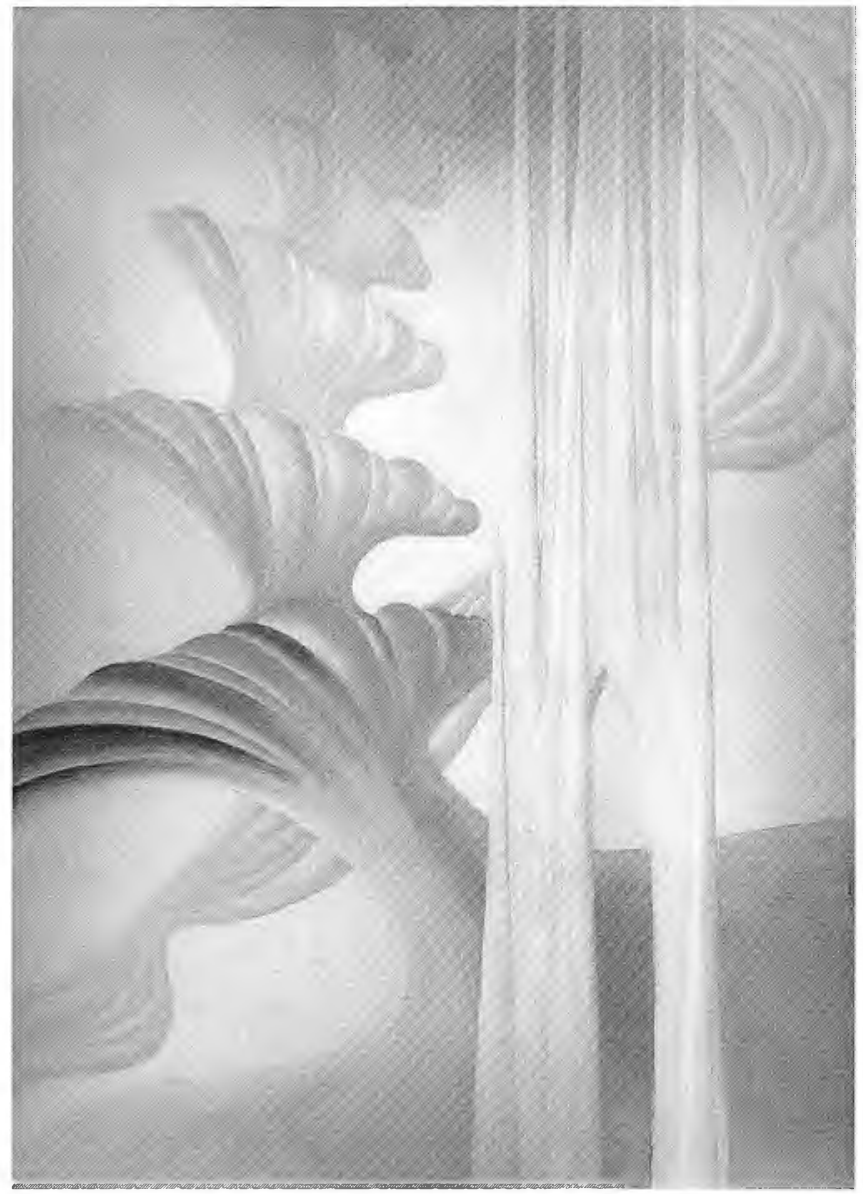

the complex counterpoint of the fugue as the voices enter in one after another. These coils appear to unfold like a succession of melodic phrases. In series of contrasting movements, they play against the vertical and horizontal columnar panels in the background which represent the stable element, analogous to the sustained pedal notes produced by the organ. The subtle, linear shading of the panels suggests variations in volume. Rhythm and movement combine to create a natural corollary, continuous and pervasive.

Brooker's Duet 1.17 (fig. 7) incorporates many of these very same devices in an effort to reproduce the spontaneous and intimate dialogue that can transpire during duet performance (e.g., flute and piano, violin and piano, etc.). The spiraling coils of the middle ground could represent a chain of melodic phrases, played with rhythmic variations by a violin in a piano and string duet while the columnar panels suggest the sustained chords of a piano. Furthermore, the sweeping, curvilinear, gestural shapes that overlap the coils resonate like extended notes played by the bow of a violinist, who now and then allows the piano to take the lead. Because of this exchange, the rhythm of Duet 1.17 appears to be quicker, brisker than the Fugue.

The artist continued his experiments with musical form in another of his paintings, Chorale (Bach) (fig. 8). He conveyed the incessant, cyclical sensation of motion with a series of swelling expanding forms which ascend and descend within space. These expanding forms express the improvisational spirit and slower, more solemn, reverent tempo of Bach's chorale preludes from the Orgelbüchlein for organ.

Augustus Bridle commented on the energetic, expanding quality in his review of Brooker's drawings, especially noting the drawings of Elijah. In his description of one of the Elijahs (most likely 1 Kings, XIX 13, of 1929), Bridle said that: "The wind is a powerful lurch of stout foreground trees - as though tons of air per square inch had jumped on them with the energy depicted in Reubke's organ sonata Out of the Deep." 68 Bertram Brooker cited the aforementioned passage from Bridle's Toronto Star review in the 9 March 1929 "Seven Arts" column to illustrate "the connection between music and the plastic arts."

The sensation of movement is also apparent in Brooker's painting, Sounds Assembling, which evolved from an earlier series of tempera paintings. In Sounds Assembling, the discordant and clashing colour tones irritate the senses like a series of unresolved dissonances while the circular forms seem to spin in 
Figure 9. Bertram Brooker, Alleluiah (or Allelujah), ca. 1929. Oil on canvas, $123.0 \times 123.3 \mathrm{~cm}$. Ottawa, National Gallery of Canada (Photo: National Gallery of Canada).

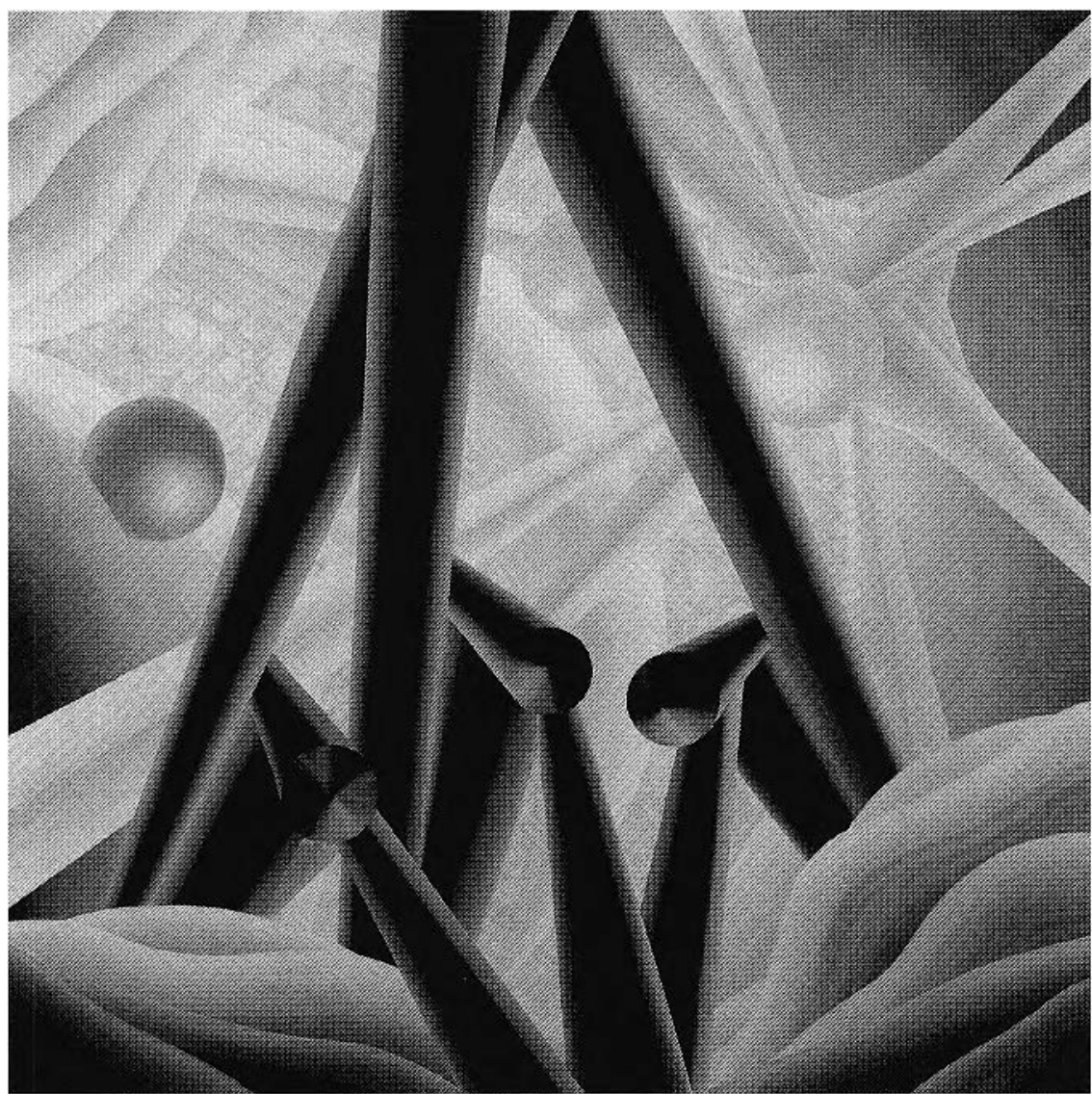

Figure 10. Bertram Brooker, Resolution, 1929-30. Oil on canvas, $60.0 \times 75.0 \mathrm{~cm}$. Art Gallery of Hamilton, Gift of the Volunteer Committee, 1983 (Photo: Art Gallery of Hamilton).

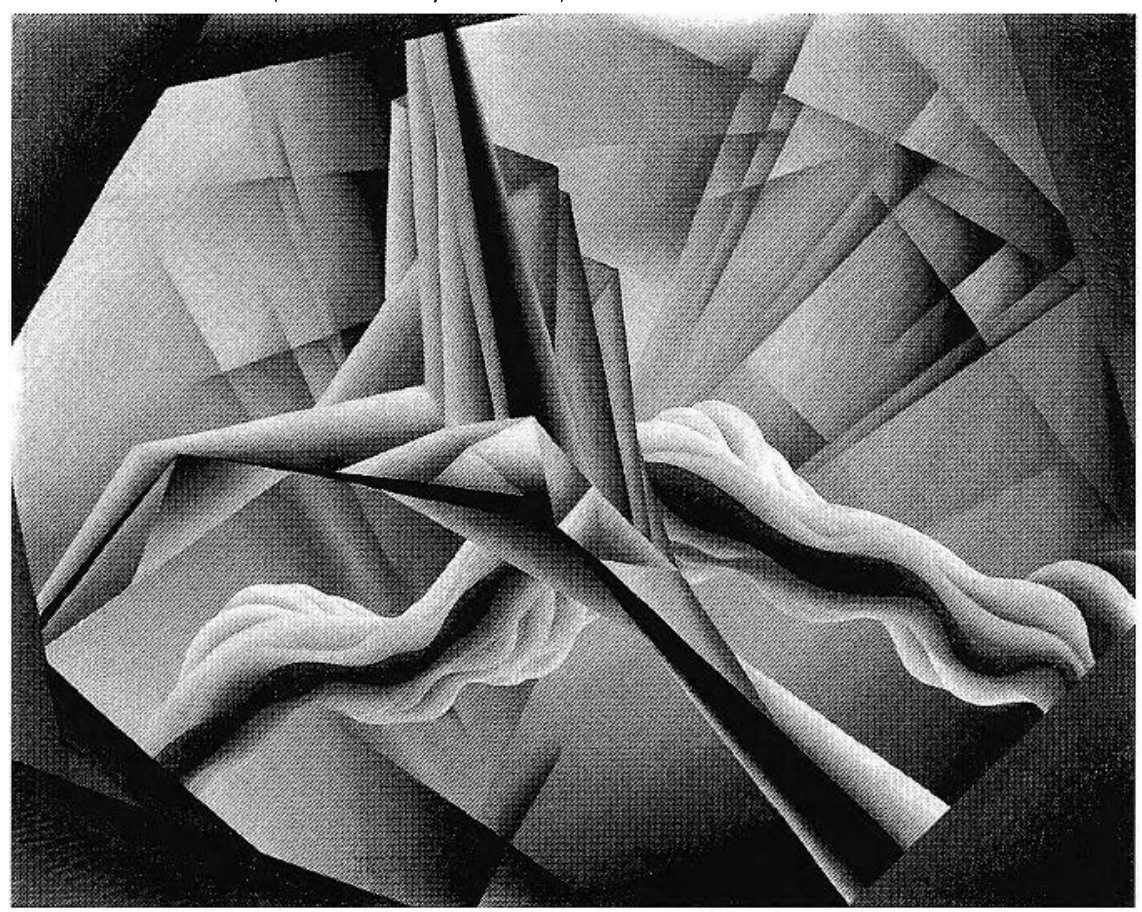

perpetual motion. In addition, Sounds Assembling could represent a type of pictorial musical score or interior view of musical structure and form. The tapered rods that emanate outwards from the centre of the white stars located within the circles (the source of the sounds) may express an array of musical tones and phrases of contrasting durations.

Victoria Evans hypothesized that the design motifs in Sounds Assembling reinforced Brooker's philosophical/spiritual premise of unity in multiplicity. The circular forms and multi-coloured tapered shafts extend beyond the confines of the picture frame, creating the illusion of them spilling out into the viewer's space:

\section{The clusters of short white shafts ex- ploding outward from a single point are a demonstration of the "unitude" of a common origin being fractured into a disjunctive, individuated "mul- titude." Even the circle motif, which ordinarily indicates the perfect self-con- tainment of the unified One, has been made to signify the infinite accretion of parts that is the All through its mul- tiplication ...The microcosm of the de- picted space bleeds into the macrocosm of the viewer's space ... ${ }^{69}$}

Likewise, the viewer becomes an active participant in Allelujah (fig. 9) in which Brooker has constructed a type of abstract scaffolding that may allude to a dramatic moment during the Hallelujah Chorus in Handel's Messiah. ${ }^{71}$ Brooker aspires to recreate the intricate polyphony of the Hallelujah Chorus by superimposing a number of oblique, dark-coloured, rod-like tubes against a brightly illuminated background. He creates spatial ambiguity while implying ongoing movement, through the interaction of these rod-like tubes and curvilinear "ribbonlike bands." 71

This spatial ambiguity is also apparent in Brooker's architectonic paintings, Ascending Forms (fig. 3) and Resolution (fig. 10), where the transparent nature of musical har- 
mony is suggested through the overlapping of forms and colours. Upon closer observation, the spherical black dots in the middle ground of Ascending Forms appear to vibrate and pulsate behind a superimposed grid-like screen. This interplay generates a repetitive, pulsating pattern which suggests the ostinato figure in music. The ostinato is a distinctive melodic fragment or rhythmic figure that is repeated continuously throughout a musical composition.

Artists like Bertram Brooker must have found it challenging to emulate such musical qualities as harmony, which has no pictorial equivalent. Its transparent quality and verticality could only be approximated through the juxtaposition and superimposition of colours and forms. Furthermore, "colours had no overtones, no 'upper partials,' and therefore could not in isolation, suggest a colour 'key' or tonal centre." 72

In Resolution, Brooker uses a variety of contrasting forms set in a shallow, faceted, cubist space to express the dynamic moment during a harmonic progression, when dissonance resolves into consonance. Resolution occurs when an unstable interval like the tri-tone of the dominant seventh chord resolves to a major third in the tonic chord of a musical composition. This feeling of closure is reinforced by the fusion of the rising tapered, oblique columns, located just left of centre in the upper sector of the painting. These works reveal Brooker's desire to develop and bring into being a series of pictorial equivalents for such musical qualities as rhythm and volume. Brooker affirmed this in an address he delivered at the Hart House:

\footnotetext{
I shamelessly used a ruler and compasses, trying to compose on the canvas some sort of replica of the colour, the volume and the rhythm I experienced when listening to music ... Most of the shapes were floating areas of colour - they were verbs, representing action and movement - and when, in some cases, they came close to recognition as objects. such as spheres or rods or peaks, these were only intended as the path or climax or culmination of a movement, nor its finish. ${ }^{73}$
}

Although Brooker had read Concerning the Spiritual in Art and believed that music could be used as a vehicle to express the inner forces, he rejected Kandinsky's attempts to establish direct correspondences between colour and sound as being "a mistaken and stultifying endeavour ..." 74 Brooker's synaesthetic sensibility was determined more by feeling and intuition than by scientific analysis. In this regard, Brooker's thoughts on the subject coincided with many other artists, including Morgan Russell who said, "Make lines colours ... never paint 'the thing' or the subject. Paint the emotion not illustration ... a few curly lines and do depth, rhythm light ... a few little spectrums, dark violets and lights ..."75

In addition to Kandinsky and Georges Braque, Brooker
Figure II. Bertram Brooker, Green Movement, ca. 1927. Oil on paper board, $58.8 \times 43.2$ cm. Toronto, Art Gallery of Ontario (Photo: Art Gallery of Ontario).

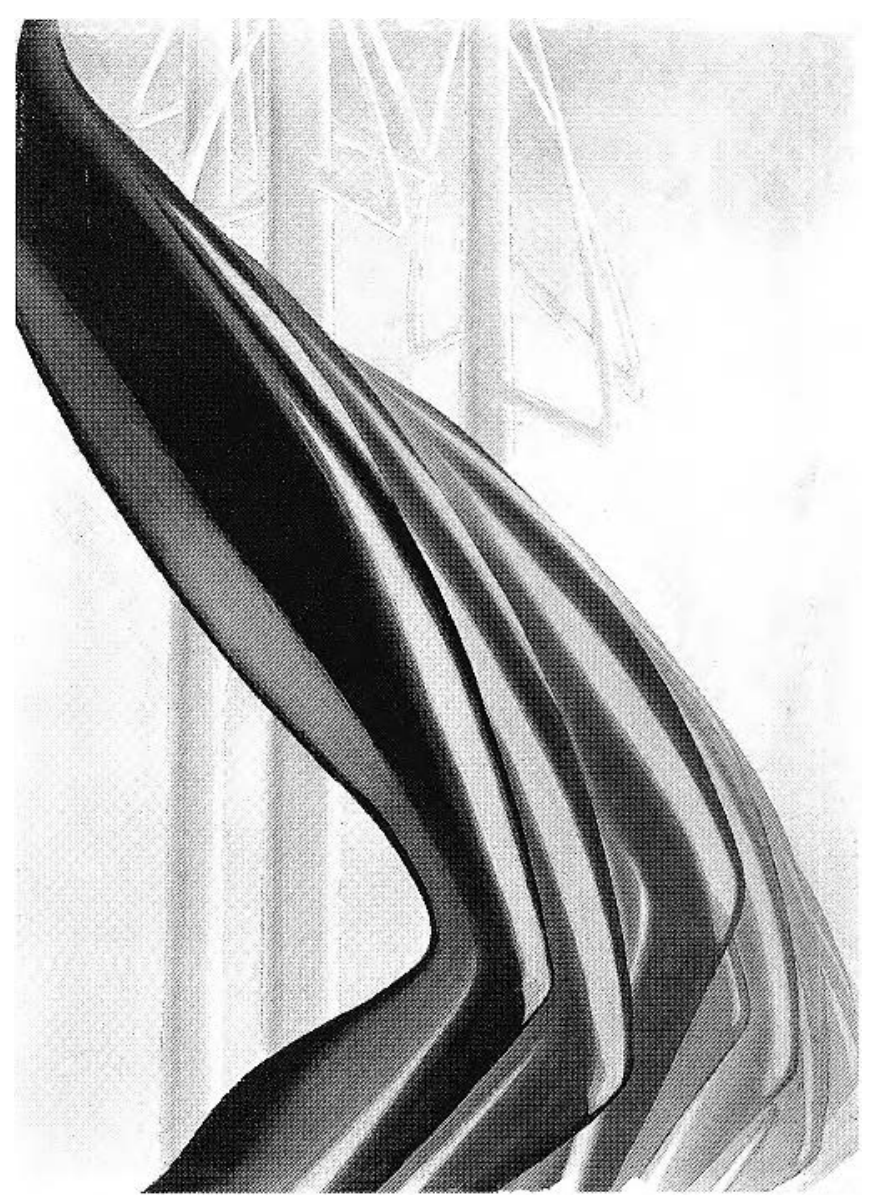

was also influenced by Georgia O'Keeffe, another artist who found inspiration in music. A work like Brooker's Green Movement (fig. 11) with its pulsating, curvaceous rhythms could easily be compared to O'Keeffe's Blue and Green Music of $1919 .^{76}$ Like O'Keeffe, Brooker was trying to suggest motion and ongoing movement in an effort to re-create the feeling of music on canvas. His use of colour and form also alludes to O'Keeffe's work. Christine Boyanoski, the author of Permeable Border, suggested that Brooker had discovered her work during one of his visits to New York City after 1921 and in reading Sheldon Cheney's A Primer of Modern Art (published in 1924). ${ }^{77}$ Georgia O'Keeffe's painting, Blue and Green Music, had been reproduced in Cheney's book. Furthermore, in 1934 Brooker attended an exhibition of her work while he was in New York. ${ }^{78}$

Brooker repudiated imitation and encouraged originality in the arts. In this respect, he believed that music was the vehicle which could transport artists beyond the material world of natural appearances and into the higher spiritual realm. "Because they [arcists] have seen beyond the material universe ... they select the most fluid forms and rhythms"79 Once artists 
entered into this higher reality, they were momentarily able to connect with the creative forces and produce works which embodied the unity which underlies multiplicity. Brooker expressed these beliefs in a poem entitled Action:

Action

The nature of Being is a constant, teeming flood of millions of actions.

At every instant, also, it is One.

Multiplicity takes flight into unity before our eyes.

That is what the word Universe means - Turning into - One.

That is what all Being is - a oneward turning.

The parts eternally make a whole

No action is free.

No living thing is free.

The beat of Being drums the march of energy through all the masquerades of matter.

Waves and winds and stars and all creatures of the earth and sea move to a pulsing measure as

harmonious as music.

The universe is a dance.

Life is a frolicking ring of joyous steps.

Rhythm is almighty. ${ }^{80}$

Bertram Brooker asserted that the true artist should be a seeker, a channel for creative energy. He clarified his ideas in an article entitled "Canada's Modern Art Movement". In the article Brooker suggested that modern artists were not concerned primarily with the accurate depiction of forms but rather the energy which flowed through them. Hence, they select only those forms "which seem to them the best 'conductors' of energy. The artist himself becomes a free channel for nature's energies or moods. If a gale of wind is blowing he tries to feel within himself the energy of the wind." 81 Expanding on this idea in his 9 March 1929 column, Brooker described a performance of Schubert's The Erl King by the famous German contralto Sigrid Onegin: "I felt she had gone to the The Erl King, for example, as a painter goes to a landscape, and had made herself, as a painter does a 'channel' through which the music could find expression." 82 In her rendition, Brooker indicated that Onegin made the song her own by drawing on her inner emotions and experiences. "I saw with thorough clearness for the first time that the interpretive function of the performer can become itself a really creative process, distinct from the notated score ..." 83 Perhaps Brooker admired Onegin because she was able to express the directness and emotional intensity of the music, qualities which he aspired to re-create in his own work.

In Wilfred's "Mobile Colour", Brooker had discovered an art form with tremendous expressive possibilities, one which, like music, unfolded in time. In his early abstract compositions, Brooker strove to convey the fourth-dimensional quality and spatial ambiguities manifest in "Mobile Colour" and in the innovative work of orher twentieth-century masters. Abstract works such as Chorale (Bach), Fugue, Duet 1.17, Sounds Assembling and Allelujah suggest that Bertram Brooker succeeded in evoking the emotive power of music and became himself a "channel" for the universal rhythms which he believed flowed through existence.

\section{Acknowledgements}

Special thanks to Rosanne Kendall, Iryna Ostapchuk and Gerald Needham.

\section{NOTES}

1 Dixon Brooke [Bertram Brooker], "The New Game of MusicColour," 1930 (?), Original, p. 2, Bertram R. Brooker Collection, Archives and Special Collections, Elizabeth Dafoe Library, University of Manitoba, Winnipeg.

2 Joyce Zemans, "First Fruits: The World and Spirit Paintings," Provincial Essays, VII (1989), 17-37, esp. 26.

3 Victor Brooker, radio interview, For Art's Sake, cassette recording, [Winnipeg], n.d., Bertram R. Brooker Collection.

4 Bertram Brooker, "The Seven Arts" column, Southam Newspaper Chain, 9 March 1929.

5 Brooker, "Seven Arts," 9 March 1929

6 "New Young Toronto Artist Paints Subjective Group," review, Toronto Star, 5 Feb. 1927, 8.

7 Victor Brooker, interview, For Art's Sake.

8 Dennis Reid, Bertram Brooker, Canadian Artists Series I (Ottawa, 1979), 10.

9 Reid, Bertram Brooker, 10.

10 Brooker, "Music-Colour," 2

11 Brooker, "Seven Arts," 19 October 1929.

12 John Gage, Colour and Culture: Practice and Meaning from Antiquity to Abstraction (Boston, 1993), 242.

13 Hans Hess, Lyonel Feininger (New York, 1959), 98

14 Peter Vergo, "Music and Abstract Painting: Kandinsky, Goethe and Schoenberg," in Towards a New Art: Essays on the Background to Abstract Art 1910-20 (London, 1980), 41-63, esp. 52.

15 Vergo, "Music and Abstract Painting," 42-43.

16 Vergo, "Music and Abstract Painting," 46.

17 Arthur Symons, Plays, Acting and Music: A Book of Theory (New York, 1909), 229; quoted in Berrram Brooker, "The Woes of Music Criticism with a Few Odd Examples," Manitoba Free Press, The Third Annual Music Supplement, 4 December 1918, 1. 
18 Victor Brooker, Toronto, to Birk Sproxton and David Arnason, Winnipeg, 9 October 1974, original, Bertram R. Brooker Collection.

19 Brooker, "Seven Arts," 23 February 1929.

20 Brooker, "Seven Arts," 12 October 1929.

21 Brooker, "Seven Arts," 19 October 1929.

22 Vergo, "Music and Abstract Painting," 41.

23 Gail Levin, Synchromism and American Color Abstraction: 19101925 (New York, 1978), 44.

24 Adrien Bernard Klein, Colour Music: The Art of Light (I ondon, 1930), 103; quoted in Levin, Synchromism, 14.

25 Brooker, "Seven Arts," 16 February 1929.

26 Healey Willan, Toronto, to Bertram Brooker, Toronto, n.d., Bcrtram R. Brooker Collection.

27 Thomas R. Lee, "Bertram Brooker, 1888-1955," Canadian Art, XIII (1956), 288.

28 Richard E. Bennett, "Bertram R. Brooker: Biographical Sketch," 1981, 4, 7, Bertram R. Brooker Collection.

29 Bennett, "Bertram Brooker: Biographical Sketch," 5.

30 Brooker, "The Woes of Music Criticism," 6.

31 Brooker, "Seven Arts," 27 September 1930.

32 Brooker, "Seven Arts," 20 April 1929.

33 Brooker, "Seven Arts," 15 February 1930.

34 Brooker, "Seven Arts," 4 May 1929.

35 Brooker, "Seven Arts," 11 May 1929.

36 Robert Fulford, "One of the Greatest Stories Never lold," Toronto Star, 30 October 1982, sec. F, 5 .

37 Brooker, "Seven Arts," 27 April 1929.

38 Brooker, "Seven Arts," 20 April 1929.

39 Brooker, "Seven Arts," 14 September 1929.

40 Brooker, "Seven Arts," 15 December 1928.

41 Brooker, "Seven Arts,"15 February 1930.

42 Brooker, "Seven Arts," 15 December 1928.

43 Brooker, "Seven Arts," 13 September 1930 and 9 March 1929.

44 Brooker, "Seven Arts," 9 March 1929.

45 Brooker, "Seven Arts," 20 April 1929.

46 Bertram Brooker, "Address at Hart House Sketch Club," Universiry of Toronto, 1927, Bertram R. Brooker Collection.

47 P. D. Ouspensky, Tertium Organum, trans. Nicholas Bessaraboff and Claude Bragdon, 2nd Amer. edn (New York, 1920; repr., Kila, Montana, 1998), 330 (page citations are to the repr. edition).

48 Victoria Evans, "Bertram Brooker's Theory of Art as Evinced in his 'The Seven Arts' columns and Early Abstractions," The Journal of Canadian Art History, IX (1986), 28-44, esp. 35.

49 Ouspensky, Tertium Organum, 331.

50 Bertram Brooker's lists of "Books That Have Influenced Me" are located in the Bertram R. Brooker Collection.

51 August Belden, New York, to Bertram Brooker, Toronto, 19 February 1924. Original. Bertram R. Brooker Collection; mentioned in Ann Davis, The Logic of Ecstacy: Canadian Mystical Painting 1920-1940 (Toronto, 1992), note 221, 195.

52 Ouspensky, Tertium Organum, 305.
53 Ouspensky, Tertium Organum, 161.

54 Bertram Brooker, "Address at Hart House"; paraphrased in Davis, The Logic of Ecstasy, 157.

55 Bertram Brooker, Sounds Assembling: The Poetry of Bertram Brooker, ed. Birk Sproxton (Winnipeg, 1980), 15.

56 Birk Sproxton, "The Subjective Underground: The Stream of Consciousness," Provincial Essays, VII (1989), 52-62, esp. 56.

57 Bertram Brooker, "The Poetry of e.e. cummings," Canadian Forum, X (July 1930), 370-71, esp. 370; paraphrased in Davis, The Logic of Ecstasy, 158.

58 Brooker, "The Poetry of e.e. cummings," 370

59 Brooker, "Seven Arts," 26 October 1929.

60 Sheldon Cheney, A Primer of Modern Art, XIV edn (1924; New York, 1966), 176-88.

61 Cheney, A Primer of Modern Art, 177.

62 Cheney, A Primer of Modern Art, 177.

63 Cheney, A Primer of Modern Art, 178.

64 Cheney, A Primer of Modern Art, 187.

65 Brooker, "Seven Arts," 16 March 1929.

66 Hess, Lyonel Feininger, 98.

67 Davis, The Logic of Ecstasy, 151.

68 Augustus Bridle, review of Brooker's Drawings, Toronto Star, n.d., quoted in Brooker, "Seven Arts," 9 March 1929.

69 Evans, "Bertram Brooker's Theory of Art," 32-33.

70 There are several spellings; the most commonly used being Hallelujah. Others include Alleluia or the less frequently used Alleluiah (National Gallery of Canada spelling). I have chosen to use Allelujah throughout the text.

71 Davis, The Logic of Ecstasy, 151.

72 Vergo, "Music and Abstract Painting," 53.

73 Brooker, Sounds Assembling, 35-36.

74 See Wassily Kandinsky, Concerning the Spiritual in Art, trans. M. T. H. Sadler (London, 1914; repr., New York, 1977). Brooker, "Seven Arts," 19 October 1929.

75 Levin, Synchromism, 18.

76 Christine Boyanoski, Permeable Border: Art of Canada and the United States 1920-1940 (Toronto, 1989), 28-33, noted the similarity between Brooker and O'Keeffe's work.

77 Boyanoski, Permeable Border, 28, 31.

78 In a letter written by Bertram Brooker, Toronto, to LeMoine Fitzgerald, Winnipeg, 15 March 1934 (Transcript, Bertram R. Brooker Collection), Brooker stated: "I was in New York about a month ago and saw several shows ... [including] Georgia O'Keeffe ..."

79 Brooker, "Address at Hart House."

80 Bertram Brooker, "Action," n.d., original, Bertram R. Brooker Collection.

81 Bertram Brooker, "Canada's Modern Art Movement," Canadian Forum, VI (June 1926), 278.

82 Brooker, "Seven Arts," 9 March 1929.

83 Brooker, "Seven Arts," 9 March 1929. 